\title{
Resistance gene expression determines the in vitro chemosensitivity of non-small cell lung cancer (NSCLC)
} Sharon Glaysher ${ }^{1}$, Dennis Yiannakis ${ }^{2}$, Francis G Gabriel ${ }^{1}$, Penny Johnson ${ }^{1}$, Marta E Polak ${ }^{1}$, Louise A Knight ${ }^{1}$, Zoe Goldthorpe ${ }^{1}$, Katharine Peregrin ${ }^{1}$, Mya Gyi ${ }^{1}$, Paul Modi'2, Joe Rahamim² ${ }^{2}$, Mark E Smith ${ }^{2}$, Khalid Amer ${ }^{3}$, Bruce Addis ${ }^{3}$, Matthew Poole ${ }^{4}$, Ajit Narayanan 5 , Tim J Gulliford ${ }^{1}$, Peter E Andreotti ${ }^{1}$ and Ian A Cree*1

Address: ${ }^{1}$ Translational Oncology Research Centre, Queen Alexandra Hospital, Portsmouth PO6 3LY, UK, ${ }^{2}$ Departments of Thoracic Surgery, Oncology and Pathology, Derriford Hospital, Plymouth, UK, ${ }^{3}$ Departments of Thoracic Surgery and Pathology, Southampton General Hospital, Southampton, UK, ${ }^{4}$ School of Computing, University of Portsmouth, Buckingham Building, Portsmouth PO1 3HE, UK and ${ }^{5}$ School of Computing and Mathematical Sciences, Auckland University of Technology, Private Bag 92006, Auckland 1142, New Zealand

Email: Sharon Glaysher - sharonglaysher@googlemail.com; Dennis Yiannakis - Dennis.Yiannakis@phnt.swest.nhs.uk; Francis G Gabriel - francis.gabriel@porthosp.nhs.uk; Penny Johnson - penny.johnson@porthosp.nhs.uk; Marta E Polak - marta.polak@googlemail.com; Louise A Knight - louise.knight@porthosp.nhs.uk; Zoe Goldthorpe - zoegold@hotmail.com; Katharine Peregrin - kate.peregrin@googlemail.com; Mya Gyi - mya.gyi@porthosp.nhs.uk; Paul Modi - paulmodi@doctors.org.uk; Joe Rahamim - Sarah.Sweetlove@phnt.swest.nhs.uk; Mark E Smith - mark.smith@phnt.swest.nhs.uk; Khalid Amer - Khalid.Amer@suht.nhs.uk; Bruce Addis - bruce.addis@suht.nhs.uk; Matthew Poole - Matthew.Poole@port.ac.uk; Ajit Narayanan - ajit.narayanan@aut.ac.nz; Tim J Gulliford - tim.gulliford@porthosp.nhs.uk; Peter E Andreotti - pandreotti@asdxbiosystems.com; Ian A Cree* - ian.cree@porthosp.nhs.uk * Corresponding author

This article is available from: http://www.biomedcentral.com/I47/-2407/9/300

(C) 2009 Glaysher et al; licensee BioMed Central Ltd.

This is an Open Access article distributed under the terms of the Creative Commons Attribution License (http://creativecommons.org/licenses/by/2.0), which permits unrestricted use, distribution, and reproduction in any medium, provided the original work is properly cited.

\begin{abstract}
Background: NSCLC exhibits considerable heterogeneity in its sensitivity to chemotherapy and similar heterogeneity is noted in vitro in a variety of model systems. This study has tested the hypothesis that the molecular basis of the observed in vitro chemosensitivity of NSCLC lies within the known resistance mechanisms inherent to these patients' tumors.

Methods: The chemosensitivity of a series of 49 NSCLC tumors was assessed using the ATP-based tumor chemosensitivity assay (ATP-TCA) and compared with quantitative expression of resistance genes measured by RT-PCR in a Taqman Array ${ }^{\mathrm{TM}}$ following extraction of RNA from formalin-fixed paraffin-embedded (FFPE) tissue.

Results: There was considerable heterogeneity between tumors within the ATP-TCA, and while this showed no direct correlation with individual gene expression, there was strong correlation of multi-gene signatures for many of the single agents and combinations tested. For instance, docetaxel activity showed some dependence on the expression of drug pumps, while cisplatin activity showed some dependence on DNA repair enzyme expression. Activity of both drugs was influenced more strongly still by the expression of anti- and pro-apoptotic genes by the tumor for both docetaxel and cisplatin. The doublet combinations of cisplatin with gemcitabine and cisplatin with docetaxel showed gene expression signatures incorporating resistance mechanisms for both agents.
\end{abstract}

Conclusion: Genes predicted to be involved in known mechanisms drug sensitivity and resistance correlate well with in vitro chemosensitivity and may allow the definition of predictive signatures to guide individualized chemotherapy in lung cancer. 


\section{Background}

The variable response to chemotherapy with platinum containing regimens in NSCLC is well recognized clinically. Patients crossing from one regimen to the alternate in clinical trials commonly show responses [1], suggesting that it might be possible to optimize therapy for individual patients if it was also possible to determine which regimen would be most effective. We and others have used cellular tumor response assays to show similar heterogeneity in NSCLC [2-5], and data from other tumor types such as ovarian cancer suggests that these tests correlate relatively well with outcome [6,7], despite the rapid development of resistance in many patients. However, such tests using primary tumour-derived cells are time-consuming to perform and need a large amount of tumor tissue, far more than it is generally feasible to obtain by bronchoscopic or needle biopsy in most lung cancer patients. This means that there is currently no direct correlation of clinical outcomes with ATP-based tumor chemosensitivity assay (ATP-TCA) results in lung cancer, but there is good evidence to suggest that low passage cell line models or primary tumour-derived cells (as used here) are more reliable predictors of chemosensitivity than cell lines [8].

It has long been a goal of cancer research to produce predictive molecular assays capable of widespread use. Single genes are rarely useful, unless they happen to be the targets of the drugs concerned, but until recently it has been difficult to produce predictive multigene signatures. In practice, there are two possible approaches to the generation of multigene signatures for predictive chemosensitivity testing. The first is to screen very large numbers of genes using hybridization arrays to generate signatures that correlate with clinical outcome [9]. The second approach is hypothesis-driven, using current knowledge of the pathways involved in resistance and sensitivity to individual drugs to generate sets of candidate genes likely to be predictive [10]. We have taken the latter approach and have designed genesets for chemosensitivity prediction based on published information and previous studies. To test this, we have examined their correlation with in vitro chemosensitivity data which allows multiple single agents and combinations to be studied, something that would clearly be impossible in patients.

In, the UK cisplatin-containing regimens are recommended for primary chemotherapy of inoperable NSCLC, and at the time we started this study, pemetrexed was not available $[11,12]$. Of these, the most commonly used in the UK are cisplatin with gemcitabine and cisplatin with docetaxel. Docetaxel is also used as a single agent for patients with reduced tolerance to chemotherapy, postsurgery or on relapse. Patients that respond to one of these regimens may respond to another: such crossover effects provide evidence of heterogeneity of chemosensitivity in NSCLC. Not all NSCLC patients will benefit from the same treatment, and the molecular mechanisms involved are still largely unknown. This study has tested the hypothesis that the molecular basis of this difference lies within the known resistance mechanisms inherent to these patients' tumors. The resistance to anti-cancer drugs involves many mechanisms [13,14], though those mechanisms involved for cisplatin, gemcitabine and taxane resistance have been extensively studied across a wide range of tumors.

Studies of cisplatin resistance in lung cancer are relatively rare, though some data exist. For example increased expression of the DNA repair enzyme ERCC1 has been associated with worse outcome in NSCLC patients treated with cisplatin-based chemotherapy [15], and has now been used with some success to predict response to platinum-based chemotherapy [16], though it is unlikely that single markers will be sufficient. The consensus seems to be that cisplatin resistance mechanisms include decreased drug accumulation, enhanced detoxification, and increased DNA repair efficiency [13]. The one exception to this is the presence of mismatch repair defects, which paradoxically increase the toxicity of cisplatin in many tumor types [17-19]. Most membrane transporters, such as pglycoprotein $(M D R 1)$ are not involved in cisplatin resistance, but the Copper-transporting ATPase $(A T P 7 B)$ has been implicated in a number of studies [20]. Detoxification of cisplatin includes gluthione conjugation, and glutathione S-transferase (GST $\pi$ ) has been implicated, as have two members of the multidrug resistance related protein family, MRP1 and MRP3, which are required to transport conjugated xenobiotics [21]. Repair of platinated DNA is primarily by nucleotide excision repair [22]. Expression of XPA, XPG, XPF, ERCC1 and ERCC2 are apparently involved, but the relative importance of each in this process is uncertain. In addition, the influence of apoptosis related genes has been implicated in resistance to cisplatin, particularly those such as BCL2 and SURVIVIN which inhibit apoptosis [14,23].

A number of studies of potential gemcitabine resistance mechanisms have been performed in lung cancer using PCR or immunohistochemical methods. Multiple membrane transporters, target enzymes, enzymes involved in the metabolism of gemcitabine and alterations in the apoptotic pathways have been implicated in sensitivity and resistance to this drug in a variety of human tumor types [24]. To date, there is evidence that several genes involved in gemcitabine metabolism, particularly human equilibrative nucleoside transporter 1 ( $h E N T 1)$ and cytosolic 5'-nucleotidase type II $(c N-I I)$, are involved in NSCLC resistance [25]. Resistance has also been linked to the expression of DNA repair genes, particularly ERCC1, 
ribonucleotide reductase subunits 1 and 2 (RRM1 and RRM2) [26], though immunohistochemical expression of these proteins, RAD51 or BRCA1 could not be shown to have an effect [27]. Recently, multidrug resistance associated protein 5 (MRP5), a membrane located pump, has also been implicated in gemcitabine drug resistance [28].

The taxanes stablise microtubules and prevent their turnover, leading to apoptosis in many rapidly dividing cell lines and some tumors. However, they are susceptible to xenobiotic pump mechanisms, including P-glycoprotein (MDR1), MRP, breast cancer related protein (BCRP) and major vault protein $(M V P)$. There has been relatively little work on the ability of cells to resist the action of taxanes based on resistance to apoptosis, but several studies suggest that this is likely to be of importance $[4,29,30]$.

It is generally assumed that the same resistance mechanisms used by cells to circumvent single agent activity will also be used against combinations of these drugs. There are few mechanistic studies of resistance to platinum with gemcitabine, or platinum with taxane to confirm or refute this supposition. However, one study by Smith et al. [31] in a series of endometrial cell lines suggested that GST $\pi$, MSH2, P53, and ERCC1 may be involved, confirming earlier single agent data implicating these mechanisms [13]. In addition, combining ERCC1 and RRM1 has been shown to have predictive efficacy for the combination of platinum and gemcitabine [32].

The current study has tested the hypothesis that the molecular basis of the observed difference in sensitivity in vitro between primary tumor-derived cells in the ATP-TCA lies within the known resistance mechanisms inherent to these patients' tumor cells. The mechanisms of cellular (i.e. non-pharmacokinetic) resistance to chemotherapy include: down-regulation of target expression, drug metabolism, membrane-located xenobiotic pumps, altered susceptibility to apoptosis, and altered growth/cell cycle or differentiation. Knowledge of these pathways enabled the design of a Taqman Array microfluidic qRT-PCR card to include 92 genes known or hypothesized to be involved in drug resistance/sensitivity to cytotoxic agents, including those described above (table 1). The Chemosensitivity Gene Expression Array (CGEA-1, CanTech Ltd, Portsmouth, UK) also included four housekeeping genes to allow standardisation of the results for comparison of individual tumor data. The CGEA is not comprehensive, but has enabled us to establish the degree to which in vitro sensitivity data correlate with gene expression data to determine the likely contribution of individual genes to drug sensitivity and resistance in NSCLC.

\section{Methods}

In this study we have used quantitative Reverse Transcriptase Polymerase Chain Reaction (qRT-PCR) to examine the expression of several transporter and metabolismrelated genes previously shown by ourselves and others (see above) to be involved in resistance to chemotherapy with cisplatin, gemcitabine or taxanes in NSCLC. In addition we have examined several other mechanisms likely to influence the effectiveness of chemotherapy which have been less commonly studied. The RT-PCR expression profiles obtained from stored formalin-fixed paraffin-embedded tissue have been compared with quantitative in vitro chemosensitivity data obtained for the same tumors using the ATP-based chemosensitivity assay (ATP-TCA).

\section{Patients and Samples}

A total of 62 specimens were obtained from surgical resections of NSCLC tumors from patients with a median age of 69 years, range $54-87$ years. There were 35 males and 27 females. Of these, 49 fresh samples proved suitable for ATP-TCA. All cases had formalin-fixed paraffin-embedded (FFPE) material taken for diagnostic histology, and gave written informed consent for the study, which received multicentre research ethics committee approval. The FFPE blocks subsequently provided a source of material for qRT-PCR. The breakdown by histological tumor type is given in table 2.

\section{ATP-TCA}

In all cases, ATP-TCA data was obtained as previously published [33,34]. Briefly, samples were transported to the laboratory in $25 \mathrm{ml}$ specimen bottles containing cooled transport medium consisting of DMEM (Sigma, Poole, Dorset, UK) with added antibiotics. Tumor cells were obtained by enzymatic dissociation, washed in a serum-free complete assay medium (CAM; DCS, Hamburg, Germany), and purified by density centrifugation to remove debris. The cells were washed and resuspended in CAM for plating in 96 well polypropylene plates at 20,000 cells per well with six dilutions of four drugs or combinations tested in triplicate with two rows of medium only and maximum inhibitor controls. At least $10 \%$ neoplastic cells for successful ATP-TCA. The drug concentrations used are given in table 3 . The plates were incubated for six days at $37^{\circ} \mathrm{C}$ with $5 \% \mathrm{CO}_{2}$, and the remaining ATP extracted with tumor cell extraction reagent (TCER; DCS). Aliquots of the extract were transferred to a white 96 well polystyrene plate to which an equal amount of luciferinluciferase was added. The resulting luminescence was read in a luminometer (MPLX, Berthold Diagnostic Systems, Germany) and the data transferred to an Excel (Microsoft) spreadsheet for analysis. The results were expressed as the percentage inhibition at each concentration tested, and a summary index representing the sum of the surviving fraction of cells at each dilution tested as 600- 
Table I: Genes included on Taqman array, classified by their major contribution to drug resistance mechanisms.

\begin{tabular}{|c|c|c|c|}
\hline Apoptosis & DNA repair & Proliferation & Pumps/Detox \\
\hline$A K T$ & ATM & APC C-term & ATP7B \\
\hline APAFI & $B R C A I$ & APC N-term & $B C R P$ \\
\hline$B A D$ & ERCCI & $\beta$-TUBULIN III & CESI \\
\hline$B A X$ & $E R C C 2$ & $\operatorname{cox} 2$ & CES2 \\
\hline$B C L 2$ & GTF2H2 & EGFR & $\mathrm{cN} \|$ \\
\hline$B C L-x(L)$ & MGMT & HER2 & $D P D$ \\
\hline BID & MLHI & HER3 & FPGS \\
\hline c-FLIP & $\mathrm{MSH} 2$ & HER4 & $\gamma H 2 A X$ \\
\hline FAS & MSH6 & HIFIA & GCLC \\
\hline FASL & RAD5I & $K 167$ & GCLM \\
\hline HSP6O & TOPO I & PI6 & GST $\pi$ \\
\hline HSP70 & TOPO Ila & $P 2 I$ & hENTI \\
\hline HSP9O & TOPO IIb & P27 & hENT2 \\
\hline IAP2 & $X P A$ & P53 & MDRI \\
\hline$I G F I$ & $X R C C I$ & VEGF & $M R P I$ \\
\hline$I G F I R$ & $X R C C 5$ & & MRP2 \\
\hline IGF2 & $X R C C 6$ & & MRP3 \\
\hline IGF2R & & & MRP4 \\
\hline $\mid G F B P I$ & & & MRP5 \\
\hline IGFBP2 & & & MRP6 \\
\hline$M C J$ & & & MRP8 \\
\hline MCLI & & & MTII \\
\hline$m T O R$ & & & MVP \\
\hline$N F k B$ & House-keeping gene & & OPRT \\
\hline PIK3CA & 185 & & RRMI \\
\hline PTEN & HPRT & & SODI \\
\hline STAT3 & PBGD & & TAPI \\
\hline
\end{tabular}


Table I: Genes included on Taqman array, classified by their major contribution to drug resistance mechanisms. (Continued)

\begin{tabular}{llc}
\hline SURVIVIN & SDHA & TAP2 \\
\hline XIAP & TBP & TAP4
\end{tabular}

Sum(Inh200....Inh6.25) [35], where 0 equals complete inhibition and 600 equals no effect.

\section{Extraction of RNA from FFPE tumor tissue}

Eight $10 \mu \mathrm{m}$ curl sections were cut from formalin-fixed paraffin-processed blocks of lung including at least $75 \%$ tumor tissue, placed in a $1.5 \mathrm{ml}$ microcentrifuge tube and heated at $70^{\circ} \mathrm{C}$ in a Stuart SBH200D heating block for 20 min to allow excess paraffin wax to be removed from the tissue using a sterile fine tip plastic pasteur pipette. Experiments with lung tissue only showed that this was unlikely to interfere with the assay (data not shown). Pre-warmed xylene $(1 \mathrm{ml})$ was then added to the tube and heated at $50^{\circ} \mathrm{C}$ for $10 \mathrm{~min}$. The microfuge tube was then removed from the heating block, at centrifuged at $12,000 \times \mathrm{g}$ for 2 min in a Sanyo MSE Microcentaur microcentrifuge. Waste xylene was then removed by pipette and the xylene wash was repeated twice more. After the final wash the tissue had uncurled.

Residual xylene was removed by the addition of $1.0 \mathrm{ml}$ of $100 \%$ ethanol to the dewaxed tissue sections, which was

Table 2: Patient histological classification in the initial surgical series used to generate signatures.

\begin{tabular}{ll}
\hline Description & Number \\
\hline Squamous cell carcinoma & 21 \\
\hline Adenocarcinoma & 20 \\
\hline Neuroendocrine NSCLC & 3 \\
\hline Poorly differentiated carcinoma & 5 \\
\hline Total on study: & 49 \\
\hline Excluded: & 4 \\
\hline - Metastatic & 1 \\
\hline - Carcinoid & 7 \\
\hline - No cells in sample & 2 \\
\hline - Contamination of sample/culture & 1 \\
\hline - Failure of assay & 64 \\
\hline Total & 4 \\
\hline
\end{tabular}

allowed to stand for $10 \mathrm{~min}$ at room temperature. The tissue was then centrifuged 12,000 $\times \mathrm{g}$ for $5 \mathrm{~min}$ and the ethanol removed by pipette, and the process repeated once more with $100 \%$ ethanol. The tissue was then rehydrated with $1.0 \mathrm{ml} 90 \%$ ethanol, for $5 \mathrm{~min}$ and finally washed in $1.0 \mathrm{ml} 70 \%$ ethanol for $5 \mathrm{~min}$. The microfuge lids were then opened to allow the ethanol to evaporate completely prior to protease digestion.

Protease digestion was performed by use of a Recoverall $\mathrm{kit}^{\mathrm{TM}}$ (Applied Biosystems, AM1975). Digestion buffer $(400 \mu \mathrm{l})$ and protease $(4 \mu \mathrm{l})$ were added to each tissue sample and incubated for 3 hours at $50^{\circ} \mathrm{C}$, with occasional flicking of the tube to assist uniform digestion. If the tissue was not digested to a clear solution, a further 60 minute incubation was performed, following which 480 $\mu$ of the Ambion RecoverAll ${ }^{\mathrm{m}}$ Isolation Additive was added to the microfuge tube, which was then vortex mixed for 20 seconds and allowed to stand for $15 \mathrm{~min}$ at room temperature. The tubes were pulse spun in a microfuge at $12,000 \times \mathrm{g}$ for 30 seconds before opening to ensure that the liquid was at the bottom of the tube and the lysate was then passed $\geq 5$ times through a $0.8 \mathrm{~mm}$ needle $(21$ gauge) fitted to a $1 \mathrm{ml}$ sterile polypropylene syringe to break up any large pieces of tissue. Two $240 \mu \mathrm{l}$ aliquots of the resulting lysate were then stored at $-20^{\circ} \mathrm{C}$ for RNA extraction.

RNA extraction was performed using the Recoverall $\mathrm{kit}^{\mathrm{TM}}$. Briefly, the sample lysate was slow thawed at $4{ }^{\circ} \mathrm{C}$ with gentle vortexing before the addition of $550 \mu \mathrm{l}$ of $100 \%$ ethanol added to each tube. Filter cartridges for RNA isolation were inserted in collection tubes, and $700 \mu \mathrm{l}$ of the lysate/ethanol mix pipetted onto the centre of each cartridge. The cartridges were centrifuged at $10,000 \times \mathrm{g}$ for 60 seconds, the flow through discarded and the filter cartridge re-inserted into the same collection tube. This was repeated twice more until all the lysate had been processed for each sample. The cartridges were washed according to the manufacturer's instructions and the flow through discarded. DNase treatment of the immobilized nucleic acids was performed by the addition of $60 \mu \mathrm{l}$ of DNase mix to the centre of each Filter Cartridge, incubation for $30 \mathrm{~min}$ at room temperature, followed by further washes. Finally, the filter cartridge was placed into a fresh collection tube and $30 \mu \mathrm{l}$ of heated $\left(95^{\circ} \mathrm{C}\right)$ nuclease free water placed into the centre of the filter. Following incubation at room temperature for 60 seconds, the filters were microfuged for 60 seconds at 13,000 rpm $(13,000 \times$ g). This was repeated to give a final volume of $60 \mu \mathrm{l}$ total 
Table 3: Drug list for ATP-TCA with manufacturer, given with the $100 \%$ test drug concentration (TDC) used in the assay, and the number of tumors tested.

\begin{tabular}{lccc}
\hline Drug or combination & Manufacturer & TDC $(\mu$ M) & Number tested \\
\hline Docetaxel & Sanofi-Aventis & 3.00 & 43 \\
\hline Cisplatin & Bristol-Myers-Squibb & 10.00 & 41 \\
\hline Gemcitabine & Eli Lilly & 40.04 & 39 \\
\hline Cisplatin with Gemcitabine & As single agents & As single agents & 38 \\
\hline Docetaxel with Cisplatin & As single agents & As single agents & 22 \\
\hline Docetaxel with Gemcitabine & As single agents & As single agents & 21 \\
\hline
\end{tabular}

Some tumors had too few cells for all agents/combinations to be tested.

RNA. Purity and quantity was checked spectrophotometry at $260 \mathrm{~nm}$ and $280 \mathrm{~nm}$ by placing $1.3 \mu \mathrm{l}$ of eluate on the sampling pedestal of a scanning NanoDrop ND-1000 spectrophotometer. Aliquots of each sample were stored at $-80^{\circ} \mathrm{C}$ or reverse transcribed to produce cDNA in a two step RT-PCR reaction.

\section{Two-step RT-PCR}

Reverse transcription was performed using an ABI HighCapacity cDNA Archive Kit (cat 4322171) according to the manufacturer's instructions. Briefly, an aliquot of 75 $\mu \mathrm{l}$ master mix was added to a $0.2 \mathrm{ml}$ PCR tube to which an equal volume of purified RNA diluted in nuclease free water was added. For RT negative wells, a $15 \mu \mathrm{l}$ master mix was prepared where the multiscibe RT volume was replaced with nuclease-free water. To this was added $15 \mu \mathrm{l}$ of diluted RNA in nuclease-free water. The final RNA concentration in the RT mix was $50 \mathrm{ng} / \mu \mathrm{l}$. The tubes were kept in a chilled cooling block until ready to load into the thermal cycler (Hybaid Omn-E). Cycling conditions were step $1,25^{\circ} \mathrm{C} \times 10 \mathrm{~min}$, step $2,37^{\circ} \mathrm{C}$ for $120 \mathrm{~min}$. After removal from the thermal cycler, the tubes were pulse spun in a microfuge at $12,000 \times \mathrm{g}$ for 30 seconds and stored overnight at $4{ }^{\circ} \mathrm{C}$ or used immediately. cDNA content was measured using a NanoDrop ${ }^{\mathrm{TM}}$ spectrophotometer prior to use in a 'sighting shot' PCR reaction which was performed for all samples to ensure housekeeping gene expression and to confirm that the cDNA was suitable for Taqman Array evaluation.

Pre-Taqman array 'sighting shot' evaluation of newly prepared cDNA was performed by SYBR green PCR for HMBS (PBGD) by adding a $5 \mu \mathrm{l}$ volumes of $10 \mu \mathrm{g}$ and $2.5 \mu \mathrm{g}$ cDNA into one of two wells of a polystyrene PCR plate, each well of which contained $20 \mu \mathrm{l}$ of master mix (diluted SYBR Green $\times 2$ master mix; Sigma Aldrich S-4438), in nuclease-free water to which primers and $\mathrm{MgCl} 2 \mathrm{had}$ been added. RT negative controls were also included for each sample. PCR was run for 40 cycles in a BioRad i-Cycler and the results transferred to a Microsoft Excel spreadsheet for analysis. Samples with cycle thresholds for detection (Cts) below 35 and undetectable results from the RT negative control were deemed evaluable for use in a Taqman array.

GCEA Taqman arrays were run according to the manufacturer's instructions. Each sample was made up with Taqman $\times 2$ Universal Master Mix and mixed with an equal volume of cDNA to give a final concentration of $300 \mathrm{ng} /$ $\mu \mathrm{l}$ suitable for the small volume dry PCR Taqman array wells. All four samples were then each pipetted into two ports $(100 \mu \mathrm{l}$ per port) of the 384 well card, for the 96 genes arrayed.

The loaded CGEA Taqman array was then placed, port upwards, into a balanced centrifuge (type, address) and spun at $380 \times \mathrm{g}$ to fill the card. This was checked and the card spun again at $380 \times \mathrm{g}$ to remove any air bubbles. The card was then placed in a Taqman array slide sealer, sealed, and the loading ports cut from the card before it was loaded into an AB 7900HT thermal cycler. PCR was performed for $90 \mathrm{~min}$ with the following conditions: AmpErase UNG Activation for $2 \mathrm{~min}$ at $50^{\circ} \mathrm{C}$; AmpliTaq Gold DNA Polymerase Activation for $10 \mathrm{~min}$ at $94.5^{\circ} \mathrm{C}$; followed by 40 cycles each of Melt Anneal/Extend for 30 sec at $97^{\circ} \mathrm{C}$ and $1 \mathrm{~min}$ at $59.7^{\circ} \mathrm{C}$.

The 'Auto Threshold Cycle' function was performed at the end of the run and resulting Ct data from the CGEA Taqman array card was transferred to a Microsoft Excel spreadsheet, controls checked, and the data transferred to a Microsoft Access database for further analysis.

During the course of the study three standard curve cards were performed using the same cDNA sample with the following final concentrations of cDNA $1100 \mathrm{ng} / \mu \mathrm{l}, 300$ 
$\mathrm{ng} / \mu \mathrm{l}, 150 \mathrm{ng} / \mu \mathrm{l}$ and $75 \mathrm{ng} / \mu \mathrm{l}$. On examining each of the multiple targets standard curves and primer/probe efficiencies, the optimal final concentration of cDNA was deemed to be $300 \mathrm{ng} / \mu \mathrm{l}$, and used for all samples. In addition, two replicate cards were run with the same cDNA samples, using three replicates at a final concentration cDNA of $300 \mathrm{ng} / \mu \mathrm{l}$, and one no template control (NTC; nuclease-free water) on each card.

$\mathrm{Ct}$ values were standardised by reference to $H M B S$ $(P B G D)$, the least variable housekeeping gene of the four present on the array, which was detected at cycle 29, to avoid errors due to differences in efficiency between the $\mathrm{HK}$ and test genes which were present from cycle $27-35$ in most cases. The standard method of analysis (deltaCt) was inappropriate for linear regression as it skews the data obtained, and therefore normalised the data by logarithmic transformation. A logarithmic gene expression ratio (GER) was calculated as $\ln \left(2^{-\mathrm{Ct}}\left[\right.\right.$ test] $\left./ 2^{-\mathrm{Ct}}[\mathrm{PBGD}]\right)$ and used for comparison with ATP-TCA data by multiple linear regression using SPSS ver 14.0 and Analyse-It software.

\section{Data Analysis}

Sample size calculations for the in vitro chemosensitivity correlation with the CGEA data were performed using an on-line multiple regression sample size calculator http:// www.danielsoper.com/statcalc based on analysis of up to 25 variables (predictors) and an anticipated r-squared of 0.5 with $80 \%$ power and alpha 0.05 , giving a required sample size of 36 patients for each drug or combination measured.

The data from ATP-TCA, and qRT-PCR studies were collected into an Access database (Microsoft), from which descriptive statistics were generated. Statistical comparison of ATP-TCA results for individual drugs (continuous dependent variable) with CGEA gene expression data was performed by multiple linear regression with forward selection of variables using SPSS ver 14.0 (SPSS Inc, Chicago, USA). For each variable, inclusion was dependent upon a probability of $\mathrm{F}>0.1$, i.e. the threshold for inclusion of a gene into the forward linear regression model within SPSS, based on initial assessment of the most appropriate model size. The PRESS (prediction residual sum of squares) graphs shown use an adjusted regression method employed to prevent overfitting, as a 'leave one out method'. No intercept was term was included, and genes were added by forward regression according to their univariate correlations following entry of each gene. The number of genes accepted into each model was based on initial assessment of the most appropriate model size using Akaike Information Criterion versus model size (data not shown). The Akaike Information Criterion (AIC) is a function of model error and size which penal- ises large models, and the lowest number is regarded as best.

\section{Results \\ ATP-TCA}

There were sufficient cells for testing of one drug or more, with evaluable results, in 52 specimens with a diagnosis of NSCLC following surgery and sufficient cells for testing. Three specimens failed to produce results in the assay: one due to low ATP counts at the end of the assay, while the other cultures became infected, probably due to low level contamination within the samples.

The results from the 49 samples with evaluable ATP-TCA data show considerable heterogeneity of chemosensitivity between tumors (figure 1) tested with single agents and combinations. Cisplatin is usually more active than docetaxel, with a steeper concentration-inhibition curve (figure 1). Of the combinations tested, cisplatin with gemcitabine was the most active in this series of experiments (figure 1), and proved more effective than cisplatin with docetaxel in the 21 tumors tested with both combinations (Wilcoxon, $\mathrm{p}<0.0001$ ). Several experimental regimens were tested. Comparison of the largest histological subgroups of NSCLC (i.e. those showing squamous or glandular differentiation) showed no difference in the effect of treatment, and no gender effects were noted on sensitivity to cisplatin, docetaxel or doxorubicin.

The ATP-TCA IndexSUM is a natural logarithmic index, ranging from $0-600$ for inhibition, with zero corresponding to complete cell kill, and 600 equating to no effect. Examination of frequency histograms and IndexSUM data (figure 2, table 4) for each of the drugs tested shows considerable heterogeneity of chemosensitivity between individual tumors for all drugs tested, with the greatest activity (i.e. lowest IndexSUM) for cisplatin with gemcitabine, and cisplatin with docetaxel. The single agents alone are relatively inactive (figure 2 ) in comparison with the combinations.

All six agents were tested in 24 tumours. Comparison of these paired results by IndexSUM (figure 3) shows the greater sensitivity of NSCLC to gemicitabine with respect to cisplatin ( $\mathrm{p}<0.001)$, and docetaxel $(\mathrm{p}<0.001)$. Cisplatin was marginally more active than docetaxel ( $\mathrm{p}<$ 0.022 ). However, in $3 / 24$ tumors, cisplatin was the most active agent, while in 3/24 tumors docetaxel was the most active agent, and in 18/24 tumors gemcitabine was the most active agent. Comparison of the three combinations tested showed that cisplatin + gemcitabine was more active than cisplatin + docetaxel $(\mathrm{p}<0.001)$, and docetaxel + gemcitabine $(p<0.001)$ though the of the two docetaxel containing regimens docetaxel \pm gemcitabine was the more active $(\mathrm{p}<0.007)$. However, there was some 
(a)

(b)
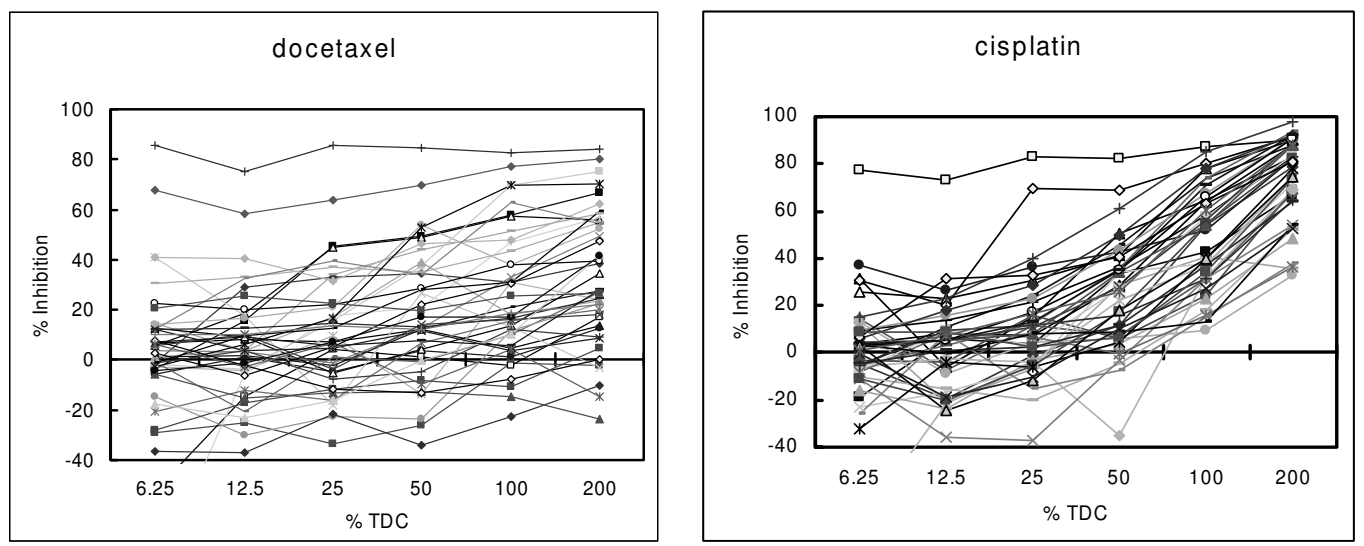

(c)

(d)
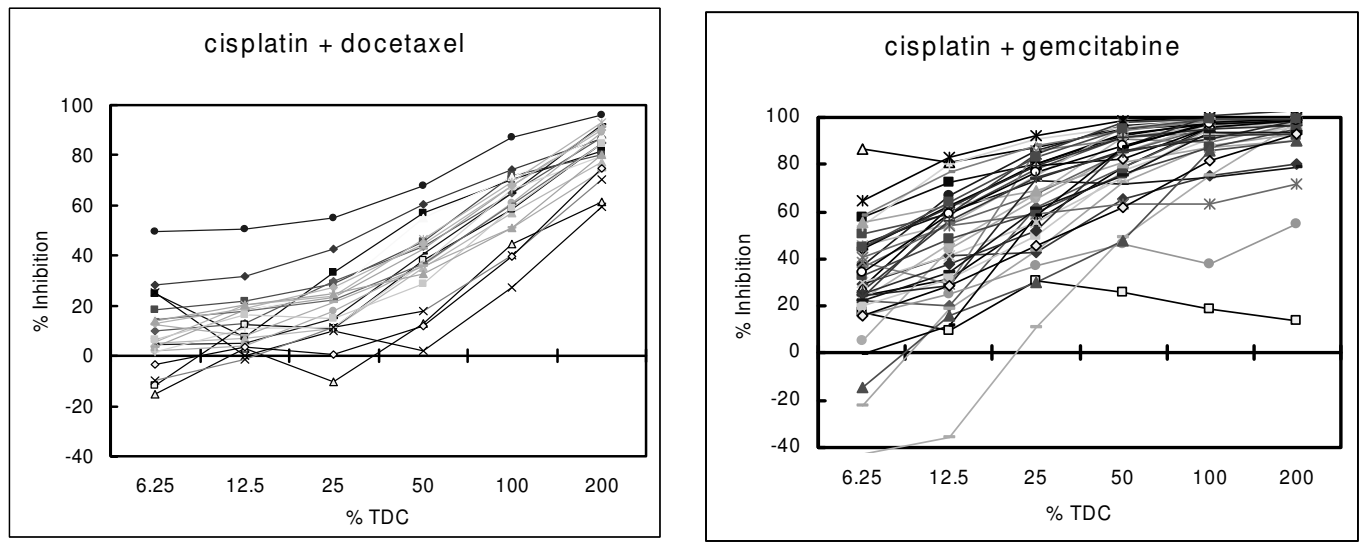

(e)

(f)
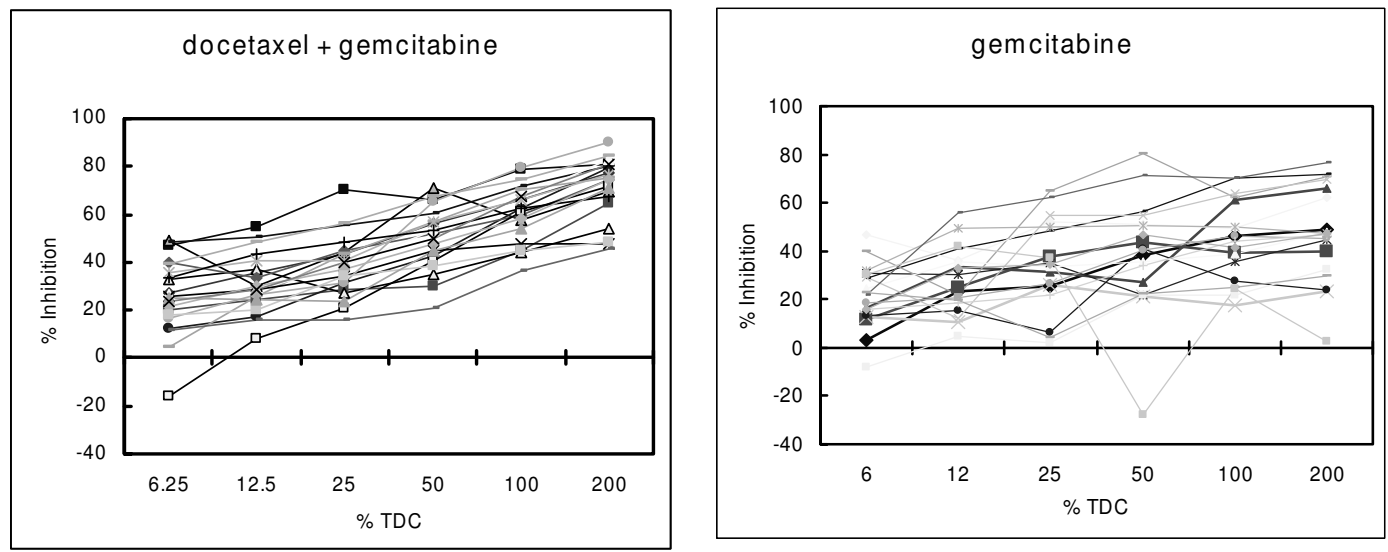

Figure I

Heterogeneity of chemosensitivity for (a) docetaxel (b) cisplatin, (c) cisplatin with docetaxel, (d) cisplatin with gemcitabine, and (e) docetaxel with gemcitabine, (f) gemcitabine. Each line represents a different tumor tested at six concentrations. 
(a)

Histogram

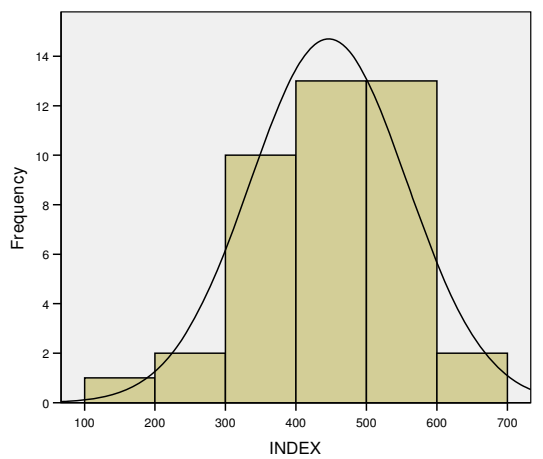

(c)

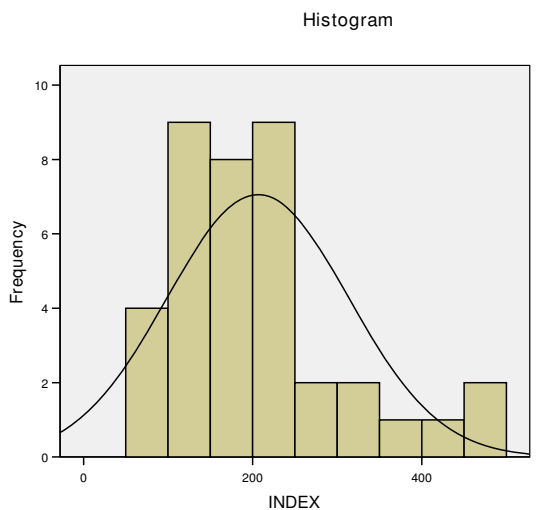

(e)

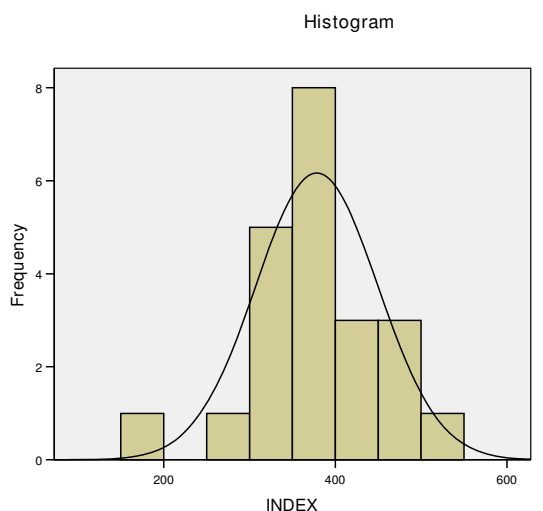

(b)

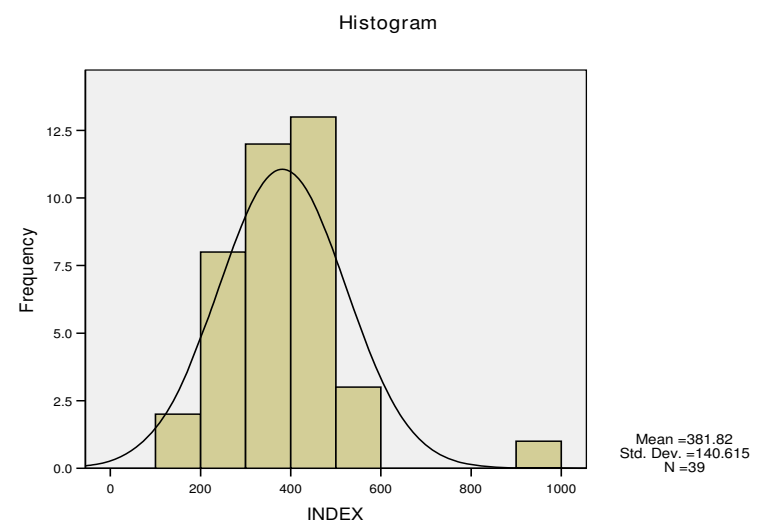

(d)

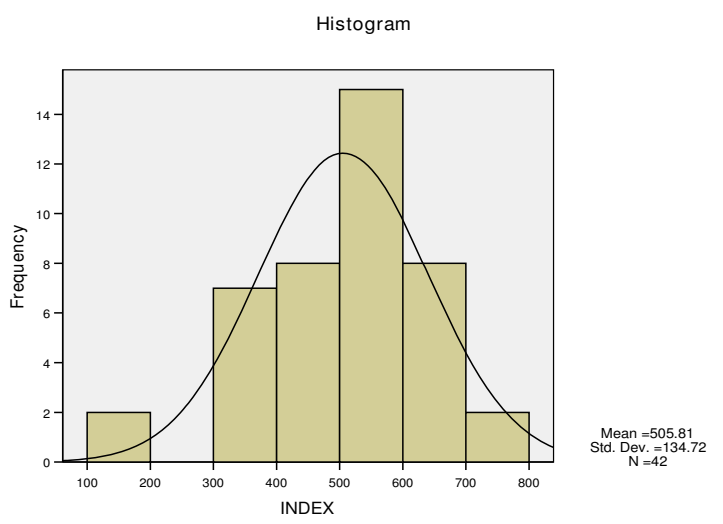

(f)

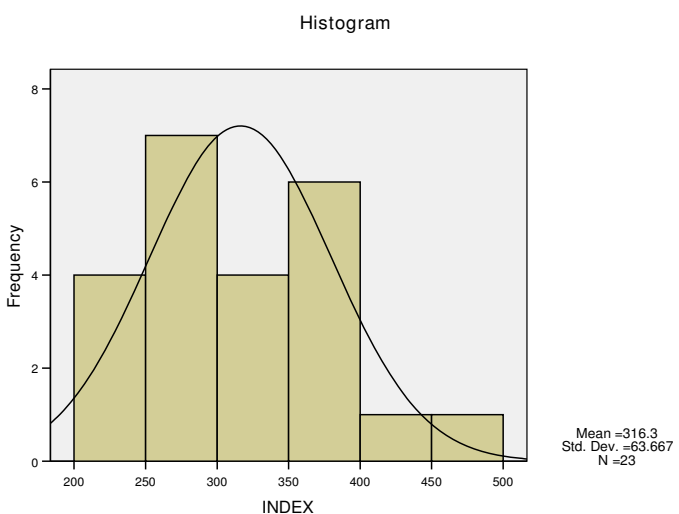

Figure 2

ATP-TCA results expressed as histograms for IndexSUM for the drugs and combinations most commonly used in NSCLC. (a) cisplatin (b) gemcitabine (c) cisplatin with gemcitabine (d) docetaxel, (e) docetaxel with cisplatin, (f) docetaxel with gemcitabine. 
Table 4: Data for each drug and combination tested, showing median and interquartile range (in brackets) for IC50, IC90 (both expressed as \% TDC) and Index sum.

\begin{tabular}{|c|c|c|c|c|}
\hline Drug/Combination & IC90 (\%TDC) & IC50 (\%TDC) & Index ${ }_{\text {SUM }}$ & Number with $>95 \%$ inhibition \\
\hline Docetaxel & $\begin{array}{c}433 \\
297-778.5\end{array}$ & $\begin{array}{c}246 \\
71-438\end{array}$ & $\begin{array}{c}523 \\
419-591\end{array}$ & $0 / 43$ \\
\hline Cisplatin & $\begin{array}{c}229 \\
204-278\end{array}$ & $\begin{array}{c}95 \\
71-156\end{array}$ & $\begin{array}{c}466 \\
378-513\end{array}$ & $0 / 41$ \\
\hline Gemcitabine & $\begin{array}{c}300 \\
242-383\end{array}$ & $\begin{array}{c}82 \\
22-213\end{array}$ & $\begin{array}{c}378 \\
293-446\end{array}$ & $0 / 39$ \\
\hline Cisplatin with Gemcitabine & $\begin{array}{c}80 \\
46-143\end{array}$ & $\begin{array}{c}13 \\
8-23\end{array}$ & $\begin{array}{c}186 \\
136-231\end{array}$ & $19 / 38$ \\
\hline Docetaxel with Cisplatin & $\begin{array}{c}213 \\
203-231\end{array}$ & $\begin{array}{c}75 \\
59-93\end{array}$ & $\begin{array}{c}378 \\
339-405\end{array}$ & $0 / 22$ \\
\hline Docetaxel with Gemcitabine & $\begin{array}{c}242 \\
224-267\end{array}$ & $\begin{array}{c}45 \\
37-78\end{array}$ & $\begin{array}{c}310 \\
290-370\end{array}$ & $0 / 21$ \\
\hline
\end{tabular}

The final column shows the number of tumors tested and those achieving $95 \%$ inhibition at the $100 \%$ TDC of those tested for each drug or combination.

heterogeneity, though in most (20/24) tumors cisplatin + gemcitabine was the most active combination, in $4 / 24$ tumors docetaxel + gemcitabine was the most active. Either were always better than cisplatin + docetaxel in this series (figure 3, table 4). ATP-TCA data can be used to generate data on additive or synergistic effects between drugs, but this analysis has not been preformed as it is of limited relevance to this paper.

\section{qRT-PCR}

Despite the use of FFPE tissue, all samples were regarded as evaluable on the basis of the housekeeping gene Ct levels (i.e. PBGD Ct $>35$ cycles). Variation in HK gene levels was limited, with a normal distribution of Ct levels (PBGD, mean 29.301 (95\% CI 28.630 - 29.971). Ct levels within the detectable range were present for most of the genes present on the Taqman array [see Additional file 1], though some were more rarely expressed than others, and NTC remained undetectable throughout the study.

The two replicate plates showed an intra-assay variation $(\mathrm{CoV})$ of $0.32 \%$ and $0.07 \%$ on $\mathrm{Ct}$ values from the same sample, while the same sample tested five times in different plates showed an inter-assay variation $(\mathrm{CoV})$ of $0.51 \%$ for $H M B S$. Two dilution plates were run during the series of Taqman arrays to assess the efficiency of the genes included on the plate. These results show 99\% efficiency for $H M B S$.

\section{Correlation of mechanisms with ATP-TCA data}

In general, comparison with genesets linked to particular resistance mechanisms showed good correlation with drugs susceptible to these mechanisms in multiple regression analysis (figure 4), provided that the drugs were active and showed heterogeneity of chemosensitivity with a spread of sensitive and resistant tumors. Although the genes chosen were not a naïve dataset, as all had been related to drug resistance or sensitivity, for the purpose of this report the SPSS analysis included all genes present on the card. Forward multiple regression models were identified for each drug or combination included in the study. The genes involved are shown in table 5, in order of greatest contribution to the model, and the coefficients for each in table 6.

Cisplatin activity showed strong correlation with resistance gene expression, particularly those genes involved in DNA repair (e.g. ATM kinase and GTF2H2) and apoptosis (e.g. IAP2, BID, MCJ, P53, mTOR, and MCL1). Few drug pumps were present in the model, though MRP5 and MVP were present, as well as two nucleotide metabolism genes, TS and FPGS. Docetaxel activity showed greater correlation with drug pump expression and detoxification mechanisms, with no relationship to DNA repair. Docetaxel showed little activity as a single agent, but was correlated with two MDR-related pumps (MRP5 and MRP8), and with GST $\pi$ expression, as well as IGF binding protein (IGFBP). Forced addition of $\beta$-TUBULIN III to the final model added no benefit to the model. Few of the genes thought to be involved in gemcitabine expression were present on the card, and only MRP4 was selected by statistical analysis, though this had a very low level of correlation with gemcitabine sensitivity (figure 4). 
(a)

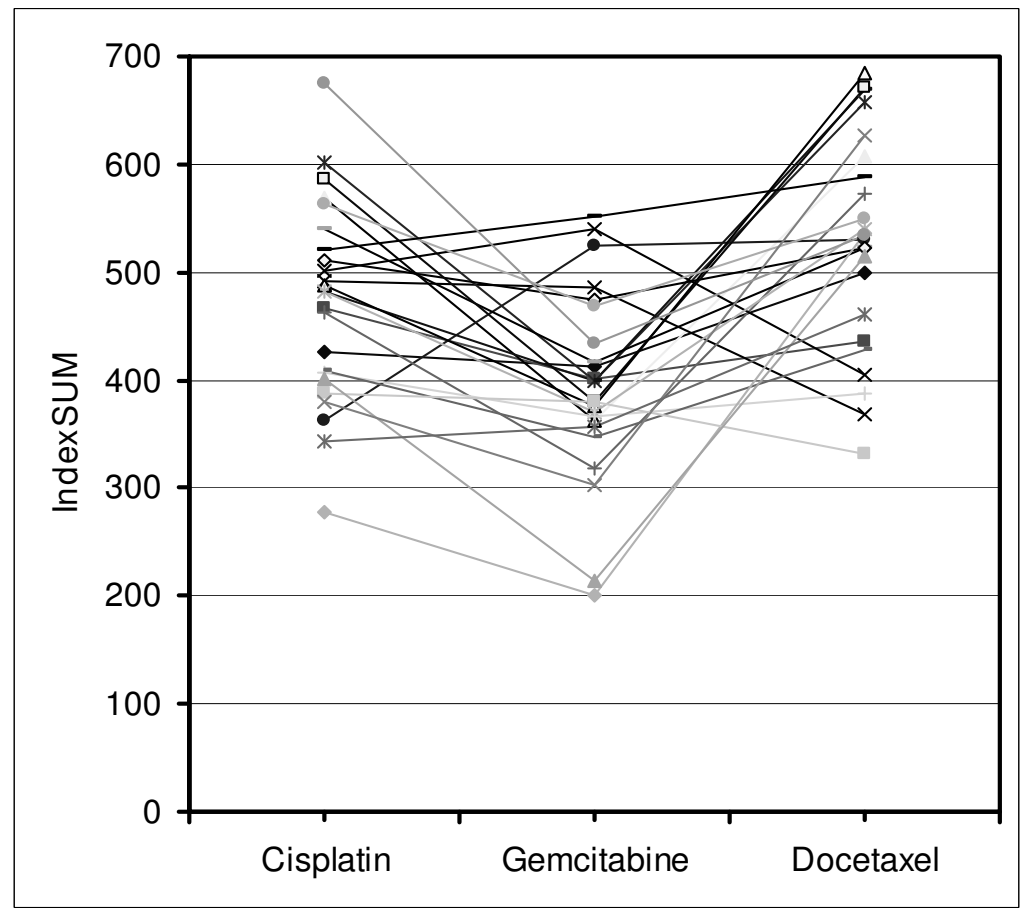

(b)

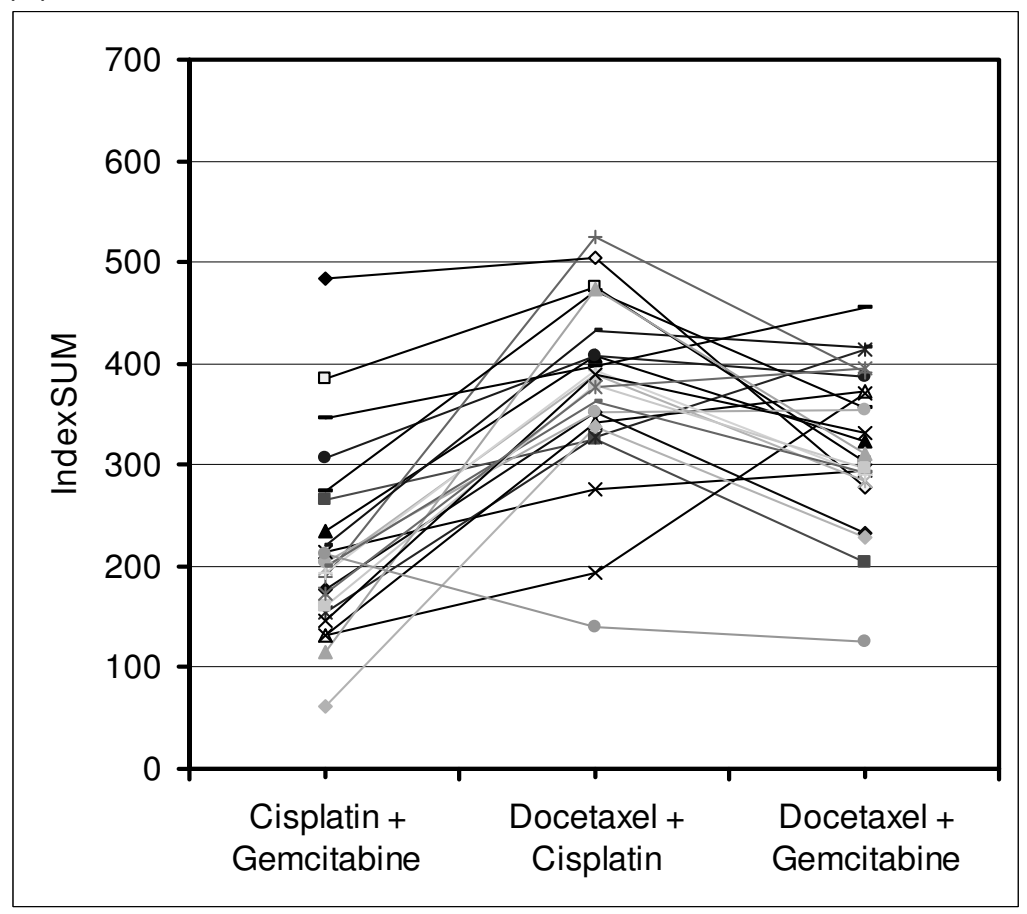

Figure 3

Cross resistance in the ATP-TCA between (a) drugs and (b) combinations, expressed as IndexSUM. 
(a)

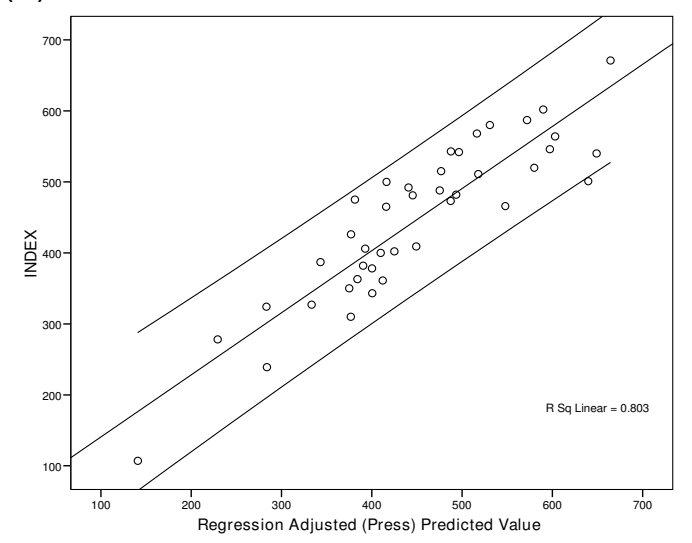

(c)

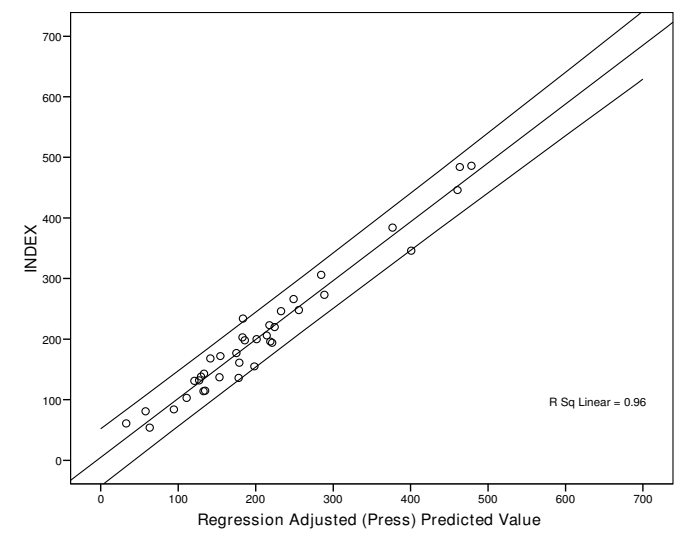

(b)

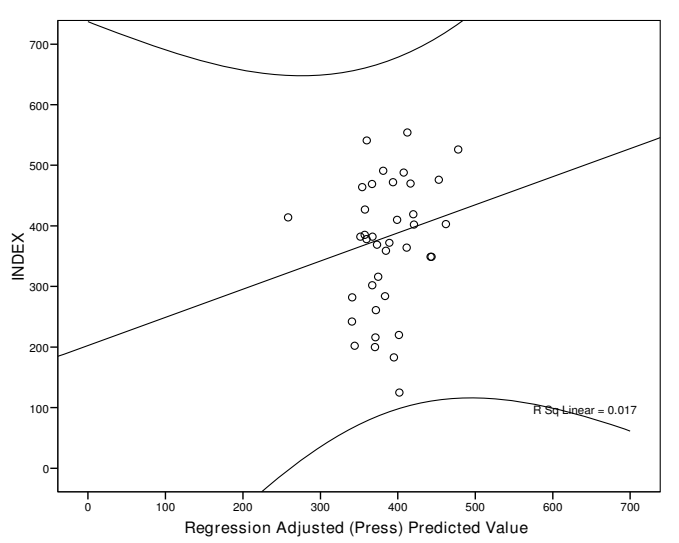

(d)

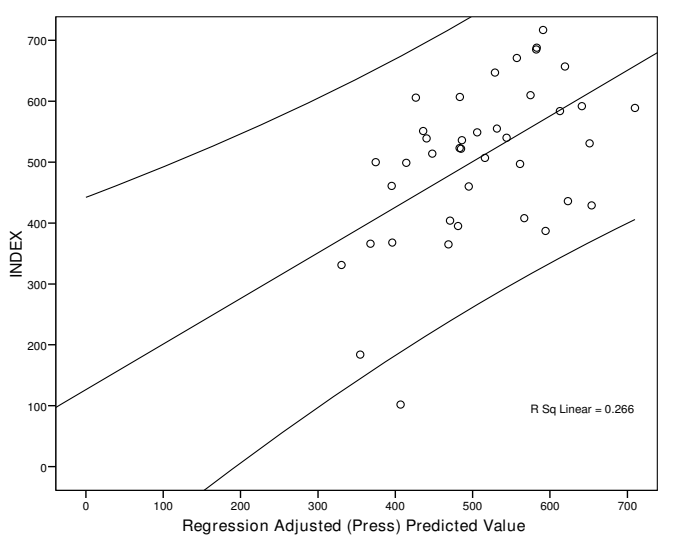

(e)

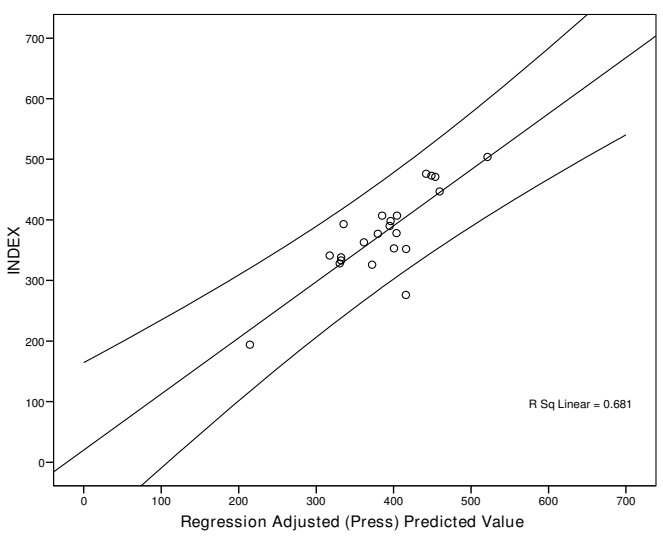

\section{Figure 4}

Multiple linear regression analysis (PRESS) by unsupervised forward selection for (a) cisplatin; (b) gemcitabine; (c) cisplatin with gemcitabine; (d) docetaxel; (e) docetaxel with cisplatin. No correlation was obtained for docetaxel with gemcitabine. 
Table 5: Genes found to correlate in multivariate linear regression analysis using forward selection: model summaries.

\begin{tabular}{lcrrrr}
\hline Model & $R$ & $R^{2}$ & Adj R & $\begin{array}{r}\text { Std. Error } \\
\text { Significance } \\
\text { (ANOVA) }\end{array}$ & 0.001 \\
\hline Cisplatin & & & & 36.976 \\
Gemcitabine & 0.965 & 0.931 & 0.892 & 136.326 & 107.579 \\
Docetaxel & 0.277 & 0.076 & 0.051 & 12.565 & 0.093 \\
Cisplatin with Gemcitabine & 0.664 & 0.441 & 0.361 & 0.001 \\
Cisplatin with Docetaxel & 0.997 & 0.995 & 0.987 & 0.001 \\
& 0.959 & 0.92 & 0.885 & 0.001
\end{tabular}

Greater levels of correlation were found between gene expression and chemosensitivity to combinations. Cisplatin with gemcitabine showed excellent correlation with a model containing 22 genes, including a number of DNA repair and apoptosis genes, though no less than 4 drug pumps are also included in this model. There were fewer observations for cisplatin with docetaxel due to the order in which drugs were tested in the ATP-TCA: some tumors contained too few cells to test all drugs. Both lists include a number of genes involved in apoptosis, as well as GST $\pi$ and drug pump molecules, together with a several genes involved in DNA repair. It is noted that the first two genes in the cisplatin with docetaxel model are APAF1, involved in apoptosis, and MLH1, a mismatch repair gene.

No tumor type-specific differences were found between adenocarcinomas and squamous cell carcinomas for any of the drugs studied.

\section{Discussion}

Use of the ATP-TCA has allowed us to examine both single and combination effects for the same tumors, and for the first time to compare chemosensitivity data with the expression of a large number of potential resistance mechanisms using a robust qRT-PCR approach with mRNA obtained from FFPE biopsy material. While the ATP-TCA requires large surgical biopsy specimens, the qRT-PCR method can be performed with a few nanograms of RNA extracted from FFPE tissue. Similar RT-PCR results to these can be produced from the much smaller samples obtained by bronchoscopic or needle biopsy (Gabriel et al., unpublished). If this approach proves to be related to clinical outcome, it may be possible to design tests to predict the efficacy of the two main chemotherapy regimens currently in use for NSCLC treatment and to optimize patient treatment on this basis.

The comparison of quantitative data from the ATP-TCA (CoV 15\%) with that from qRT-PCR (CoV 2\%) has the advantage that relatively small numbers of tumors are required to obtain data on the genes relevant to resistance and sensitivity to drugs tested in the assay. This may prove to be particularly useful to investigate the mechanisms of sensitivity and resistance for drugs which are rarely used as single agents in specific tumor types, and for new drugs which have not yet entered the clinic. However, for single agents, there is less sensitivity, and less variation between patients in the ATP-TCA, and therefore lower levels of correlation with gene expression were found for the single agents.

The Taqman array card included all of the genes described in the introduction to this paper, but was manufactured before some more recent papers were published which suggest that others may also be important. For instance, for gemcitabine, other genes involved include human concentrative nucleoside transporter ( $h C N T 3)$, deoxycitidine kinase $(d C K)$, cytidine deaminase $(C D A)$, Cytidine deaminase $(C D D)$ and 5 '-nucleotidase $(5 N T)$ gene polymorphisms and $C D D, 5 N T$, deoxycytidine kinase (DCK) and MRP5 [28,36]. Further work is therefore required to define genesets that might be clinically useful.

The genes identified in this study fall into several categories, linked with much studied mechanisms such as metabolism within the cell, membrane drug pumps, and DNA repair, but also with apoptosis, suggesting that the general susceptibility of the cell to undergo this process may be an important determinant of tumor chemosensitivity, outweighing more specific mechanisms [14]. The genes found to be important by unsupervised forward selection multiple regression match well with those thought to be important from previous studies in cell lines and multiple tumor types. Other statistical methods have been applied (data not shown), including analysis of principal components, cluster analysis and supervised regression models. All show a similar ability to derive models which describe the data, and the importance of genes related to particular resistance/sensitivity mechanisms seem to hold up remarkably well. Inevitably there are some discrepancies between the published literature and our findings, but the number of tumors is as yet relatively small and it is important not to read too much into the individual genes within the models.

Most combinations used in lung cancer have been derived empirically from phase II and phase III clinical trials. However, synergy has been observed in cell lines between cisplatin and several agents: notably taxanes and gemcitabine. The basis of this synergy is unclear for platinum 
Table 6: Genes found to correlate in multivariate linear regression analysis using forward selection: coefficients for each gene included in the model by drug or combination tested.

\begin{tabular}{|c|c|c|c|c|c|c|}
\hline \multirow[b]{2}{*}{ Gene } & \multicolumn{2}{|c|}{ Unstandardized } & \multirow{2}{*}{$\begin{array}{l}\text { Standardized } \\
\text { Beta }\end{array}$} & \multirow{2}{*}{$\begin{array}{l}\mathrm{t} \\
\text { Lower Bound }\end{array}$} & \multicolumn{2}{|c|}{ Collinearity Statistics } \\
\hline & B & Std. Error & & & B & Std. Error \\
\hline \multicolumn{7}{|l|}{ Cisplatin } \\
\hline (Constant) & 403.123 & 33.393 & & 12.072 & & \\
\hline GTF2H2 & 64.781 & 16.558 & 0.573 & 3.912 & 0.129 & 7.725 \\
\hline IAP2 & -153.15 & 16.813 & -2.122 & -9.109 & 0.051 & 19.57| \\
\hline MRP5 & 71.075 & 8.946 & 0.799 & 7.945 & 0.274 & 3.651 \\
\hline P53 & -91.289 & 11.062 & -0.63 & -8.252 & 0.476 & 2.101 \\
\hline ATM kinase & 105.764 & 14.77 & 1.494 & 7.161 & 0.064 & $|5.7|$ \\
\hline FPGS & 30.449 & 9.411 & 0.391 & 3.235 & 0.19 & 5.263 \\
\hline mTOR & -14.902 & 14.509 & -0.146 & -1.027 & 0.137 & 7.273 \\
\hline$T S$ & 42.031 & 7.318 & 0.584 & 5.744 & 0.269 & 3.724 \\
\hline$M C J$ & 92.954 & 14.616 & 0.908 & 6.36 & 0.136 & 7.355 \\
\hline$B I D$ & -49.393 & 12.785 & -0.402 & -3.863 & 0.256 & 3.9 \\
\hline Topo I & -72.192 & 17.437 & -0.688 & -4.14 & 0.1 & 9.957 \\
\hline Mcl-I & 57.031 & 12.755 & 0.69 & 4.471 & 0.116 & 8.597 \\
\hline HER2 & -12.172 & 5.364 & -0.179 & -2.269 & 0.448 & 2.233 \\
\hline MVP & -30.265 & 13.535 & -0.197 & -2.236 & 0.357 & 2.805 \\
\hline \multicolumn{7}{|c|}{ Gemcitabine } \\
\hline (Constant) & 338.553 & 35.306 & & 9.589 & & \\
\hline MRP4 & -28.047 & $16.24 \mid$ & -0.277 & -1.727 & I & I \\
\hline \multicolumn{7}{|l|}{ Docetaxel } \\
\hline (Constant) & 778.346 & 103.411 & & 7.527 & & \\
\hline MRP5 & 62.715 & 14.617 & 0.623 & 4.291 & 0.757 & 1.322 \\
\hline$G S T \pi$ & -77.649 & 24.429 & $-0.46 I$ & -3.179 & 0.76 & 1.316 \\
\hline IGFBP2 & -25.582 & 12.653 & -0.265 & -2.022 & 0.933 & 1.072 \\
\hline IGFBPI & 28.488 & 10.056 & 0.411 & 2.833 & 0.76 & 1.316 \\
\hline MRP8 & -22.098 & 9.513 & -0.333 & -2.323 & 0.777 & 1.287 \\
\hline \multicolumn{7}{|c|}{ Cisplatin with Gemcitabine } \\
\hline (Constant) & 350.892 & 41.063 & & 8.545 & & \\
\hline$B A X$ & 51.989 & $|1.96|$ & 0.273 & 4.346 & 0.094 & 10.64 \\
\hline HER3 & -10.321 & 4.863 & -0.098 & -2.122 & 0.172 & 5.813 \\
\hline$M R P 3$ & -19.569 & 1.948 & -0.371 & -10.044 & 0.272 & 3.681 \\
\hline$A K T$ & -150.08 & 7.205 & -1.064 & -20.831 & 0.142 & 7.063 \\
\hline MRP8 & 26.222 & 2.484 & 0.45 & 10.556 & 0.203 & 4.915 \\
\hline MRP5 & 43.708 & 3.634 & 0.474 & 12.026 & 0.238 & 4.209 \\
\hline$B C L-x(L)$ & 178.422 & 11.378 & 1.177 & 15.682 & 0.066 & 15.23 \\
\hline EGFR & -46.006 & 4.356 & -0.47 & -10.562 & 0.187 & 5.353 \\
\hline hENT2 & 32.558 & 4.365 & 0.427 & 7.458 & 0.113 & 8.855 \\
\hline$X R C C 5$ & 90.76 & 6.702 & 0.547 & 13.543 & 0.227 & 4.412 \\
\hline IGFBPI & -5.027 & 2.315 & -0.086 & -2.171 & 0.235 & 4.26 \\
\hline$c N$ II & -73.932 & 9.164 & -0.562 & -8.067 & 0.076 & 13.146 \\
\hline HPRT & 49.176 & 4.955 & 0.715 & 9.925 & 0.071 & 14.029 \\
\hline RRMI & -69.228 & 7.483 & -0.63 & -9.251 & 0.08 & 12.527 \\
\hline PI6 & 7.663 & 2.017 & 0.146 & 3.798 & 0.251 & 3.989 \\
\hline TAP2 & -43.744 & 6.008 & -0.284 & -7.281 & 0.243 & 4.115 \\
\hline MGMT & 45.697 & 6.513 & 0.377 & 7.016 & 0.128 & 7.799 \\
\hline$A T P 7 B$ & -7.418 & 2.019 & -0.14 & -3.675 & 0.255 & 3.928 \\
\hline$K 167$ & -8.882 & 2.763 & -0.161 & -3.215 & 0.147 & 6.807 \\
\hline TOPO Ila & -6.788 & 1.708 & -0.137 & -3.973 & 0.311 & 3.218 \\
\hline$B C R P$ & 13.738 & 3.335 & 0.191 & 4.12 & 0.172 & 5.8 \\
\hline VEGF & 12.683 & 5.573 & 0.098 & 2.276 & 0.199 & 5.034 \\
\hline \multicolumn{7}{|c|}{ Cisplatin with Docetaxel } \\
\hline (Constant) & 178.403 & 46.289 & & 3.854 & & \\
\hline APAFI & 38.159 & 5.752 & 0.855 & 6.635 & 0.345 & 2.899 \\
\hline MLHI & -63.725 & 6.467 & -1.339 & -9.854 & 0.31 & 3.223 \\
\hline
\end{tabular}


Table 6: Genes found to correlate in multivariate linear regression analysis using forward selection: coefficients for each gene included in the model by drug or combination tested. (Continued)

\begin{tabular}{|c|c|c|c|c|c|c|}
\hline PTEN & $-20.68 \mid$ & 3.038 & -0.689 & -6.808 & 0.56 & 1.787 \\
\hline $\mathrm{GST}_{\pi}$ & 25.097 & $10.45 \mid$ & 0.224 & 2.401 & 0.657 & 1.523 \\
\hline$A T P 7 B$ & 10.975 & 4.529 & 0.332 & 2.423 & 0.306 & 3.269 \\
\hline$B C L-x(L)$ & 24.707 & 11.05 & 0.25 & 2.236 & 0.459 & 2.177 \\
\hline
\end{tabular}

with docetaxel, but is likely to be indirect as platinum is a DNA-damaging agent, while taxanes stabilize microtubules. In contrast, there several groups have shown that gemcitabine can reverse resistance to cisplatin by its inhibition of DNA repair [24,37]. Gemcitabine is only incorporated during DNA replication or repair. Since most solid tumors have a relatively low S-phase fraction, single agent gemcitabine has limited activity (though continuous administration may be cytostatic [38]. Concomitant administration of a DNA damaging agent, such as platinum, leading to upregulated DNA repair will have two effects. Firstly, gemcitabine will be incorporated more readily into DNA of non-dividing cells, and secondly, its ability to inhibit DNA polymerase will tend to prevent resistance to the DNA-damaging agent [39]. The effect on DNA repair seems to occur at much lower concentrations of gemcitabine than direct incorporation, suggesting that there is no need to use high doses of gemcitabine in platinum with gemcitabine combinations. This explains the potency of this regimen in NSCLC, but clearly resistant patients exist, and indeed some tumors in this study were more sensitive to alternative regimens.

While reverse resistance can help to explain why there are so few genes in common when cisplatin and gemcitibane (MRP5, MCL1, MVP) and cisplatin and docetaxel (GST $\pi$, MRP8, FPGS, P53, DPD, IAP2) are used together as opposed to separately (Table 6), the number of extra genes correlated when cisplatin is used in combination with gemcitabine $(n=19)$ and docetaxel $(n=14)$ indicates that there may be still unknown linkages and pathways between NSCLC-related genes that need further exploration.

One of the main reasons behind our decision to study NSCLC first was that there are two common types with very different histopathology and oncogenesis. The finding that there is no difference between the adenocarcinomas and squamous cell carcinomas in this series suggests that resistance and sensitivity to cytotoxic agents, at least, is determined by the gene expression profile of the cell for a particular drug, and that tumor type is of lesser importance. This fits with current clinical practice in which drugs such as cisplatin, docetaxel, and gemcitabine are used for a wide range of different solid tumor types, albeit with varying success.

\section{Conclusion}

In conclusion, the data presented here support the hypothesis that the molecular basis of the observed difference in sensitivity between NSCLC tumors lies within the known resistance mechanisms inherent to these patients' tumors. It suggests that the Taqman array is ideally suited to investigate the presence of these mechanisms in lung tumors alongside cellular chemosensitivity testing with individual drugs or combinations, and this may be of particular relevance to decision making during drug development.

\section{Competing interests}

IAC is a director of CanTech Ltd. The remaining authors declare that they have no competing interests.

\section{Authors' contributions}

IAC, DY, PEA, TJG and AN conceived and designed the study. SG, LAK, MEP, ZG and KP participated in the ATPTCA studies. FGG, PJ, MEP, LAK, and KP carried out the qRT-PCR studies. Clinical aspects of the study including recruitment, ethics, consent, planning and analysis involved DY, MG, PM, JR, KA, IAC and TJG. Histopathology was performed by MES, BA and IAC. IAC, AN and MP participated in the statistical analysis. All authors participated in the data analysis, drafting of the manuscript and read and approved the final version.

\section{Additional material}

\section{Additional file 1}

The Taqman array.

Click here for file

[http://www.biomedcentral.com/content/supplementary/1471-

2407-9-300-S1.pdf]

\section{Acknowledgements}

We are grateful to Sarah Sweetlove for her assistance in ensuring that tumor material was handled correctly, and to all the surgeons and oncologists who submitted material for chemosensitivity testing to make this study possible. We are indebted to Chirag Patel for assistance in analyzing the data. This study was funded by CanTech Ltd and Sanofi-Aventis Ltd. We are grateful to Dr Peter John Davies for his assistance in performing this study.

\section{References}

I. Fossella FV, DeVore R, Kerr RN, Crawford J, Natale RR, Dunphy F, Kalman L, Miller V, Lee JS, Moore M, et al.: Randomized phase III trial of docetaxel versus vinorelbine or ifosfamide in patients 
with advanced non-small-cell lung cancer previously treated with platinum-containing chemotherapy regimens. The TAX 320 Non-Small Cell Lung Cancer Study Group. J Clin Oncol 2000, 18( I 2):2354-2362.

2. Vogt U, Zaczek A, Klinke F, Granetzny A, Bielawski K, Falkiewicz B: p53 Gene status in relation to ex vivo chemosensitivity of non-small cell lung cancer. I Cancer Res Clin Oncol 2002, 128(3): $14 \mid-147$

3. Kawamura M, Gika M, Abiko T, Inoue Y, Oyama T, Izumi Y, Kobayashi $\mathrm{H}$, Kobayashi K: Clinical evaluation of chemosensitivity testing for patients with unresectable non-small cell lung cancer (NSCLC) using collagen gel droplet embedded culture drug sensitivity test (CD-DST). Cancer Chemother Pharmacol 2007, 59(4):507-5।3.

4. Inoue $Y$, Gika M, Abiko T, Oyama T, Saitoh Y, Yamazaki H, Nakamura M, Abe $Y$, Kawamura M, Kobayashi K: Bcl-2 overexpression enhances in vitro sensitivity against docetaxel in non-small cell lung cancer. Oncol Rep 2005, I 3(2):259-264.

5. Vogt U, Striehn E, Bosse U, Klinke F, Falkiewicz B: Lack of squamous cell lung carcinoma in vitro chemosensitivity to various drug regimens in the adenosine triphosphate cell viability chemosensitivity assay. Acta Biochim Pol 1999, 46(2):299-302.

6. Kurbacher CM, Cree IA, Bruckner HW, Brenne U, Kurbacher JA, Muller K, Ackermann T, Gilster TJ, Wilhelm LM, Engel H, et al.: Use of an ex vivo ATP luminescence assay to direct chemotherapy for recurrent ovarian cancer. Anticancer Drugs 1998, 9(I):5I-57.

7. Konecny G, Crohns C, Pegram M, Felber M, Lude S, Kurbacher C Cree IA, Hepp $H$, Untch M: Correlation of drug response with the ATP tumorchemosensitivity assay in primary FIGO stage III ovarian cancer. Gynecol Oncol 2000, 77(2):258-263.

8. Fiebig HH, Maier A, Burger AM: Clonogenic assay with established human tumour xenografts: correlation of in vitro to in vivo activity as a basis for anticancer drug discovery. Eur J Cancer 2004, 40(6):802-820.

9. Wigle DA, Jurisica I, Radulovich N, Pintilie M, Rossant J, Liu N, Lu C, Woodgett J, Seiden I, Johnston M, et al.: Molecular profiling of non-small cell lung cancer and correlation with disease-free survival. Cancer Res 2002, 62(II):3005-3008.

10. Kikuchi T, Daigo Y, Katagiri T, Tsunoda T, Okada K, Kakiuchi S, Zembutsu H, Furukawa Y, Kawamura M, Kobayashi K, et al.: Expression profiles of non-small cell lung cancers on cDNA microarrays: identification of genes for prediction of lymph-node metastasis and sensitivity to anti-cancer drugs. Oncogene 2003, 22(14):2192-2205.

II. Felip E, Stahel RA, Pavlidis N: ESMO Minimum Clinical Recommendations for diagnosis, treatment and follow-up of nonsmall-cell lung cancer (NSCLC). Ann Oncol 2005, I 6(Suppl I):i28-29.

12. Pfister DG, Johnson DH, Azzoli CG, Sause W, Smith TJ, Baker S Jr, Olak J, Stover D, Strawn JR, Turrisi AT, et al.: American Society of Clinical Oncology treatment of unresectable non-small-cell lung cancer guideline: update 2003. J Clin Oncol 2004, 22(2):330-353.

13. Cree IA, Knight L, Di Nicolantonio F, Sharma S, Gulliford T: Chemosensitization of solid tumors by modulation of resistance mechanisms. Curr Opin Investig Drugs 2002, 3(4):634-640.

14. Cree IA, Knight L, Di Nicolantonio F, Sharma S, Gulliford T: Chemosensitization of solid tumor cells by alteration of their susceptibility to apoptosis. Curr Opin Investig Drugs 2002, 3(4):64I-647.

15. Olaussen KA, Dunant A, Fouret $P$, Brambilla E, Andre F, Haddad V, Taranchon E, Filipits M, Pirker $\mathrm{R}$, Popper $\mathrm{HH}$, et al.: DNA repair by $E R C C I$ in non-small-cell lung cancer and cisplatin-based adjuvant chemotherapy. N Engl J Med 2006, 355(I 0):983-99I.

16. Simon G, Sharma A, LiX, Hazelton T, Walsh F, Williams C, Chiappori A, Haura E, Tanvetyanon T, Antonia S, et al.: Feasibility and efficacy of molecular analysis-directed individualized therapy in advanced non-small-cell lung cancer. I Clin Oncol 2007, 25(19):274|-2746.

17. Brown R, Hirst GL, Gallagher WM, Mcllwrath AJ, Margison GP, Zee AG van der, Anthoney DA: hMLHI expression and cellular responses of ovarian tumour cells to treatment with cytotoxic anticancer agents. Oncogene 1997, I (1):45-52.
18. Plumb JA, Strathdee G, Sludden J, Kaye SB, Brown R: Reversal of drug resistance in human tumor xenografts by 2'-deoxy-5azacytidine-induced demethylation of the hMLHI gene promoter. Cancer Res 2000, 60(2I):6039-6044.

19. Fedier A, Fink D: Mutations in DNA mismatch repair genes: implications for DNA damage signaling and drug sensitivity (review). Int J Oncol 2004, 24(4): 1039 - 1047

20. Rabik CA, Njoku MC, Dolan ME: Inactivation of O6-alkylguanine DNA alkyltransferase as a means to enhance chemotherapy. Cancer Treat Rev 2006, 32(4):26I-276.

21. Young LC, Campling BG, Cole SP, Deeley RG, Gerlach JH: Multidrug resistance proteins MRP3, MRPI, and MRP2 in lung cancer: correlation of protein levels with drug response and messenger RNA levels. Clin Cancer Res 200I, 7(6): I798-1804.

22. Cummings $M$, Higginbottom K, McGurk C], Wong OG, Koberle B, Oliver RT, Masters JR: XPA versus ERCCI as chemosensitising agents to cisplatin and mitomycin $C$ in prostate cancer cells: role of ERCCI in homologous recombination repair. Biochem Pharmacol 2006, 72(2): 166-175.

23. Siddik ZH: Cisplatin: mode of cytotoxic action and molecular basis of resistance. Oncogene 2003, 22(47):7265-7279.

24. Mini E, Nobili S, Caciagli B, Landini I, Mazzei T: Cellular pharmacology of gemcitabine. Ann Oncol 2006, I7(Suppl 5):v7-v/2.

25. Seve P, Mackey JR, Isaac S, Tredan O, Souquet PJ, Perol M, Cass C, Dumontet $C$ : $\mathbf{c N}$-II expression predicts survival in patients receiving gemcitabine for advanced non-small cell lung cancer. Lung Cancer 2005, 49(3):363-370.

26. Bepler G, Kusmartseva I, Sharma S, Gautam A, Cantor A, Sharma A Simon G: RRMI modulated in vitro and in vivo efficacy of gemcitabine and platinum in non-small-cell lung cancer. J Clin Oncol 2006, 24(29):473I-4737.

27. Wachters FM, Wong LS, Timens W, Kampinga HH, Groen HJ: ERCCI, hRad5I, and BRCAI protein expression in relation to tumour response and survival of stage III/IV NSCLC patients treated with chemotherapy. Lung Cancer 2005, 50(2):2II-2I9.

28. Maring JG, Groen HJ, Wachters FM, Uges DR, de Vries EG: Genetic factors influencing pyrimidine-antagonist chemotherapy. Pharmacogenomics J 2005, 5(4):226-243.

29. Zhao J, Kim JE, Reed E, Li QQ: Molecular mechanism of antitumor activity of taxanes in lung cancer (Review). Int J Oncol 2005, 27(I):247-256.

30. Yoshino T, Shiina H, Urakami S, Kikuno N, Yoneda T, Shigeno K, Igawa $\mathrm{M}$ : Bcl-2 expression as a predictive marker of hormonerefractory prostate cancer treated with taxane-based chemotherapy. Clin Cancer Res 2006, I 2(20 Pt I):6I I6-6I24.

3I. Smith JA, Gaikwad A, Ramondetta LM, Wolf JK, Brown J: Determination of the mechanism of gemcitabine modulation of cisplatin drug resistance in panel of human endometrial cancer cell lines. Gynecol Oncol 2006, I03(2):518-522.

32. Rosell R, Cobo M, Isla D, Camps C, Massuti B: Pharmacogenomics and gemcitabine. Ann Oncol 2006, I7(Suppl 5):v|3-v|6.

33. Andreotti PE, Cree IA, Kurbacher CM, Hartmann DM, Linder D, Harel G, Gleiberman I, Caruso PA, Ricks SH, Untch M, et al:: Chemosensitivity testing of human tumors using a microplate adenosine triphosphate luminescence assay: clinical correlation for cisplatin resistance of ovarian carcinoma. Cancer Res 1995 , 55(22):5276-5282

34. Cree IA: Luminescence-based cell viability testing. Methods in Molecular Biology 1998, 1998(102):169-177.

35. Hunter EM, Sutherland LA, Cree IA, Dewar JA, Preece PE, Wood RA Linder D, Andreotti PE: Heterogeneity of chemosensitivity in human breast carcinoma: use of an adenosine triphosphate (ATP) chemiluminescence assay. Eur J Surg Oncol 1993, 1 9(3):242-249.

36. Giovannetti E, Del Tacca M, Mey V, Funel N, Nannizzi S, Ricci S, Orlandini C, Boggi U, Campani D, Del Chiaro M, et al.: Transcription analysis of human equilibrative nucleoside transporterI predicts survival in pancreas cancer patients treated with gemcitabine. Cancer Res 2006, 66(7):3928-3935.

37. van Moorsel CJ, Pinedo HM, Smid K, Comijn EM, Voorn DA, Veerman G, Lakerveld B, Vijgh WJ Van der, Giaccone G, Postmus PE, et al.: Schedule-dependent pharmacodynamic effects of gemcitabine and cisplatin in mice bearing Lewis lung murine nonsmall cell lung tumours. Eur J Cancer 2000, 36( I8):2420-2429. 
38. Anderson H, Hopwood P, Stephens RJ, Thatcher N, Cottier B, Nicholson M, Milroy R, Maughan TS, Falk SJ, Bond MG, et al.: Gemcitabine plus best supportive care (BSC) vs BSC in inoperable non-small cell lung cancer - a randomized trial with quality of life as the primary outcome. UK NSCLC Gemcitabine Group. Non-Small Cell Lung Cancer. Br J Cancer 2000, 83(4):447-453.

39. Peters GJ, Wilt CL van der, van Moorsel CJ, Kroep JR, Bergman AM, Ackland SP: Basis for effective combination cancer chemotherapy with antimetabolites. Pharmacol Ther 2000, 87(23):227-253.

\section{Pre-publication history}

The pre-publication history for this paper can be accessed here:

http://www.biomedcentral.com/1471-2407/9/300/pre pub

Publish with Bio Med Central and every scientist can read your work free of charge

"BioMed Central will be the most significant development for disseminating the results of biomedical research in our lifetime. "

Sir Paul Nurse, Cancer Research UK

Your research papers will be:

- available free of charge to the entire biomedical community

- peer reviewed and published immediately upon acceptance

- cited in PubMed and archived on PubMed Central

- yours - you keep the copyright

Submit your manuscript here:

http://www.biomedcentral.com/info/publishing_adv.asp
BioMedcentral 